\title{
Comparing the performance of Turkish deposit banks by using DEMATEL, Grey Relational Analysis (GRA) and MOORA approaches ${ }^{12}$
}

\author{
Serhat Yüksel $^{3}$, Hasan Dinçer ${ }^{4}$, Şenol Emir ${ }^{5}$ \\ Received: 23/08/2017; Revised: 30/10/2017; Accepted: 27/11/2017
}

\begin{abstract}
The purpose of the study is to measure the financial performance in Turkish banking sector and to combine the data mining with the multi-criteria decision-making methods. For this purpose, a text-mining process is applied to measure the pairwise comparison of the criteria and the results are used in the integrated models. DEMATEL-GRA and DEMATEL-MOORA are defined as two integrated models. The results show that integrated models give the coherent outcomes and the text-mining process could be adapted properly in the multi-criteria decision-making methods. It is also concluded that foreign banks have better performance in comparison with state and private banks.
\end{abstract}

Keywords: Turkish Banking Sector, GRA, DEMATEL, MOORA

JEL Codes: C51, G21, L25

\footnotetext{
${ }^{1}$ This study was presented in "I. International Symposium on Economics, Finance, and Econometrics (ISEFE)" on 21.09.2017.

${ }^{2}$ Acknowledgements The authors are grateful for comments received from the referees.

3 Asst.Prof., Istanbul Medipol University, School of Business and Management, Beykoz, 34810, Istanbul, Turkey, serhatyuksel@medipol.edu.tr

${ }^{4}$ Assoc.Prof., Istanbul Medipol University, School of Business and Management, Beykoz, 34810, Istanbul, Turkey, hdincer@medipol.edu.tr

5 Asst.Prof., Istanbul University, The Department of Econometrics, 34452- Beyazit, Istanbul, Turkey, senol.emir@istanbul.edu.tr
} 


\section{Introduction}

The main function of the banks in an economy is to intermediate between economic agents that need funds to satisfy their needs or to invest and those that have funds to lend thanks to their savings (Yüksel, 2017). Thus, banks play a crucial role in the economy. First, they contribute to increase the investment. Hence, they have a positive influence on the economic growth. In addition, they also help economic agents with savings to earn more money. Lastly, they help to decrease unemployment rate in the country as they employ many people (Yüksel and Zengin, 2017).

Owing to the aspects emphasized above, the banking sector is accepted as one of the key sectors in the economy. Hence, their performance should be high for the sustainability of economic growth. However, banks are subject to many different risks due to their operations. For instance, there is a risk that debtors cannot pay their debts to the banks. In addition, banks may suffer important losses because of the volatility in the market (Oktar and Yüksel, 2016). As a result, the performance of the banks should be evaluated periodically in order to prevent any problems in the sector.

Turkey is a country that suffered from two different banking crises both in 1994 and in 2000 . Especially after the second crisis, Turkey adopted many different programs to improve the quality of the banking sector. For example, Banking Regulation and Supervision Agency was founded in this period to control the risks of Turkish banks. Owing to these kinds of reforms, it can be said that there is an improvement in the performance of Turkish banking sectors.

The aim of this study is to evaluate the performance of Turkish banking sector. For this purpose, DEMATEL, Grey Relational Analysis (GRA) and MOORA multi-criteria decisionmaking approaches are used. Hence, it will be possible to see which banks are more successful in Turkey. By this way, recommendations can be presented in order for Turkish banks to increase their performance. Another key point is that by using these new and original methods, it is believed that this study makes an important contribution to the literature.

This study consists of 6 different parts. After the introduction, the second part gives general information about Turkish banking sector. Within this context, the number of the banks and employees and amount of total assets, loans and deposits will be analyzed. The third part surveys the similar studies in the literature. In the fourth part, DEMATEL, GRA and MOORA approaches will be detailed. The fifth part gives information about the application in Turkish banking sector. In the final part, recommendations about the results will be shared.

\section{General Information About Turkish Banking Sector}

Banking sector plays a key role for Turkey. They support many companies to make investments and employ many people. Some general information regarding the sector is given in Table 1. There were 52 banks in Turkey in 2016. Deposit banks have the highest percentage in comparison with development and investment banks and participation banks. 
In deposit banks, foreign banks have the highest numbers (21) and private banks have the second highest number (9). Additionally, there are 3 state banks in Turkey. Moreover, 13 development and investment banks and 5 participation banks operate in Turkey. On the other side, private banks have the highest number of personnel. Moreover, although there are only 3 state banks, their numbers of employee are quite similar to the numbers of foreign banks.

Table 1: Number of Banks and Employees in 2016

\begin{tabular}{|c|c|c|}
\hline Type of the Banks & Number of Banks & $\begin{array}{c}\text { Number of Employees } \\
\text { (thousand people) }\end{array}$ \\
\hline Deposit Banks & 34 & 191 \\
\hline$\bullet \quad$ State Banks & 3 & 58 \\
\hline$\quad$ Private Banks & 9 & 60 \\
\hline$\quad$ Foreign Banks & 21 & 0.2 \\
\hline$\bullet \quad$ Controlled by SDIF & 1 & 5 \\
\hline Development and Investment Banks & 13 & 15 \\
\hline Participation Banks & 5 & $\mathbf{2 1 1}$ \\
\hline Total & $\mathbf{5 2}$ & \\
\hline
\end{tabular}

Source: The Banks Association of Turkey

The information about the proportion of assets, loans, and deposits of different types of the banks is demonstrated in Table 2. Deposit banks are the most important bank categories in Turkey because $90 \%$ of the total assets in banking sector is held by deposit banks. In addition, they also have $90 \%$ of total loans and $94 \%$ of total deposits. In deposit banks, private banks have the highest percentage in all categories. Moreover, state banks have the second highest percentages of total assets, loans, and deposits. Another important point is that participation banks have a very small percentage in Turkish banking sector.

Table 2: Asset, Loan and Deposit Distribution of the Banks in 2016

\begin{tabular}{|c|c|c|c|}
\hline Type of the Banks & Total Assets (\%) & Total Loans (\%) & Total Deposits (\%) \\
\hline Deposit Banks & 90 & 90 & 94 \\
\hline$\bullet \quad$ State Banks & 30 & 30 & 31 \\
\hline$\bullet \quad$ Private Banks & 35 & 36 & 38 \\
\hline$\bullet \quad$ Foreign Banks & 25 & 24 & 25 \\
\hline Development and Investment Banks & 5 & 6 & 6 \\
\hline Participation Banks & 5 & 4 & - \\
\hline
\end{tabular}

Source: The Banks Association of Turkey

\section{Literature Review}

The subject of bank performance attracted the attention of many different researchers in the literature. Some of these studies are shown in Table 3.

Table 3 shows that some of the studies in the literature aimed to compare the performance of different types of banks. Nagano (2016) made a study to analyze this issue in 11 emerging 
economies. By inspecting regression analysis results, it was concluded that state banks are more profitable, but take more risk than other banks. In spite of this study, Saghi-Zedek (2016) reached the opposite results. He worked on 710 different European banks by using the same methodology. It was emphasized that state banks have lower performance in comparison with others. Moreover, Shaban and James (2017) also underlined the similar results by using the same methodology for Indonesia. On the other hand, Akhigbe et. al. (2017b) focused on US banking sector and identified that there is not an important difference between the performance of public and private banks.

Furthermore, some studies emphasized the importance of bank specific factors in the performance of the banks. Dong et. al. (2016) made a study for China by using regression analysis. They found a positive relationship between the size and the performance of the banks. Gerhardt and Vander Vennet (2016) also emphasized the similar results for 114 European banks with the help of logit method. Additionally, Bitar et. al. (2016) worked for the countries in MENA region by using regression analysis. They found that there is a positive relationship between capital adequacy ratio and the performance of the banks. Sun et. al. (2017) and de Bandt et. al. (2017) also reached the same results by using a different technique. In addition, Salim et. al. (2016) and King et. al. (2016) concluded that the education level of CEOs has a positive influence on the performance of the banks.

With respect to the bank specific factors, some studies underlined that technical efficiency of the banks is important to increase the performance. Chai et. al. (2016) made a study for Malaysia by using regression analysis. They reached the conclusion that technological efficiency of the banks improves the performance. Meles et. al. (2016) also emphasized the similar results for US banking sector by using the same methodology. Juo et. al. (2016) focused on Taiwanese banking sector by using data envelopment analysis. They concluded that technical efficiency of the banks affects the profitability. In addition to the technological efficiency, Bian and Deng (2017) and Fukuyama and Matousek (2017) identified that there is a relationship between non-performing loans and the performance of the banks.

Additionally, country specific factors were also underlined in some different studies. For example, Mirzaei and Moore (2016) made a study of the banking sector in Qatar. By using regression analysis technique, they identified that industry growth improves the performance of the banks. In addition, Ghosh (2016) focused on 169 different countries by using generalized method of moment approach and concluded that globalization has a decreasing effect on the profitability of the banks. Moreover, Mamatzakis and Bermpei (2016) tried to analyze the banking sector in the US. With the help of dynamic panel threshold analysis, they determined that unconventional monetary policies have a negative influence on the performance of the banks. Furthermore, Ali and Azmi (2016) made a study to evaluate the banking sector in Malaysia. With the help of generalized method of moment approach, they reached the conclusion that religious orientation does not have any effect on the performance of the banks. 
Table 3: Featured Studies in the Literature

\begin{tabular}{|c|c|c|c|}
\hline Author & Scope & Model & Result \\
\hline $\begin{array}{l}\text { Mirzaei and Moore } \\
(2016)\end{array}$ & Qatar & $\begin{array}{l}\text { Regression } \\
\text { Analysis }\end{array}$ & $\begin{array}{l}\text { There is a relationship between industry growth and bank } \\
\text { performance. }\end{array}$ \\
\hline Ghosh (2016) & $\begin{array}{l}169 \text { different } \\
\text { countries }\end{array}$ & GMM & $\begin{array}{l}\text { Banking-sector globalization has a decreasing effect on the } \\
\text { profitability of the banks. }\end{array}$ \\
\hline Chai et. al. (2016) & Malaysia & $\begin{array}{c}\text { Regression } \\
\text { Analysis }\end{array}$ & $\begin{array}{l}\text { The technological efficiency of the banks increases the } \\
\text { performance. }\end{array}$ \\
\hline Salim et. al. (2016) & Australia & $\begin{array}{l}\text { Data Envelopment } \\
\text { Analysis }\end{array}$ & $\begin{array}{l}\text { Board size and committee meetings have a positive impact on } \\
\text { the performance of the banks. }\end{array}$ \\
\hline Dong et. al. (2016) & China & $\begin{array}{c}\text { Regression } \\
\text { Analysis }\end{array}$ & $\begin{array}{l}\text { There is a positive relationship between the size and the } \\
\text { performance of the banks. }\end{array}$ \\
\hline King et. al. (2016) & US & $\begin{array}{l}\text { Regression } \\
\text { Analysis }\end{array}$ & $\begin{array}{l}\text { The education level of CEOs has a positive influence on the } \\
\text { performance of the banks. }\end{array}$ \\
\hline Meles et. al. (2016) & US & $\begin{array}{l}\text { Regression } \\
\text { Analysis }\end{array}$ & Technologic improvement of the banks increases profitability. \\
\hline Nagano (2016) & $\begin{array}{l}11 \text { emerging } \\
\text { economies }\end{array}$ & $\begin{array}{l}\text { Regression } \\
\text { Analysis }\end{array}$ & $\begin{array}{l}\text { It is understood that state banks take more risk than other types } \\
\text { of the banks. }\end{array}$ \\
\hline Bitar et. al. (2016) & MENA Region & $\begin{array}{l}\text { Regression } \\
\text { Analysis }\end{array}$ & $\begin{array}{l}\text { There is a positive relationship between capital adequacy ratio } \\
\text { and the performance of the banks. }\end{array}$ \\
\hline Cai et. al. (2016) & China & $\begin{array}{l}\text { Regression } \\
\text { Analysis }\end{array}$ & $\begin{array}{l}\text { Geographical expansion improves the performance of the } \\
\text { banks. }\end{array}$ \\
\hline Saghi-Zedek (2016) & $\begin{array}{l}710 \text { European } \\
\text { banks }\end{array}$ & $\begin{array}{l}\text { Regression } \\
\text { Analysis }\end{array}$ & State banks have lower performance in comparison with others. \\
\hline $\begin{array}{l}\text { Mamatzakis and } \\
\text { Bermpei (2016) }\end{array}$ & US & $\begin{array}{c}\text { Dynamic Panel } \\
\text { Threshold } \\
\text { Analysis }\end{array}$ & $\begin{array}{l}\text { Unconventional monetary policies have a negative influence on } \\
\text { the performance of the banks. }\end{array}$ \\
\hline Ali and Azmi (2016) & Malaysia & GMM & $\begin{array}{l}\text { Religion orientation does not have any effect on the } \\
\text { performance of the banks. }\end{array}$ \\
\hline Juo et. al. (2016) & Taiwan & $\begin{array}{l}\text { Data Envelopment } \\
\text { Analysis }\end{array}$ & Technical efficiency of the banks affects the profitability. \\
\hline $\begin{array}{l}\text { Gerhardt and Vander } \\
\text { Vennet (2016) }\end{array}$ & $\begin{array}{l}114 \text { European } \\
\text { banks }\end{array}$ & Logit & $\begin{array}{l}\text { Capital adequacy ratio, size and the quality of the loans are } \\
\text { main indicators of the performance of the banks. }\end{array}$ \\
\hline Cornett et al. (2016) & US & $\begin{array}{l}\text { Regression } \\
\text { Analysis }\end{array}$ & $\begin{array}{l}\text { Corporate social responsibility activities affect the performance } \\
\text { of the banks. }\end{array}$ \\
\hline Bian and Deng (2017) & China & $\begin{array}{l}\text { Regression } \\
\text { Analysis }\end{array}$ & $\begin{array}{l}\text { Non-performing loan ratio is the most significant indicator of } \\
\text { the performance of the banks. }\end{array}$ \\
\hline Jawadi et. al. (2017) & 12 Islamic banks & $\begin{array}{l}\text { Regression } \\
\text { Analysis }\end{array}$ & The performance of Islamic banks depends on the region. \\
\hline Sun et. al. (2017) & $\begin{array}{c}105 \text { different } \\
\text { commercial } \\
\text { banks }\end{array}$ & GMM & $\begin{array}{l}\text { Capital adequacy ratio and management quality influence the } \\
\text { performance of the banks. }\end{array}$ \\
\hline Scott et. al. (2017) & $\begin{array}{l}29 \text { different } \\
\text { countries }\end{array}$ & $\begin{array}{c}\text { Regression } \\
\text { Analysis }\end{array}$ & $\begin{array}{l}\text { Adoption of the SWIFT system has an important effect on the } \\
\text { performance of the banks. }\end{array}$ \\
\hline $\begin{array}{l}\text { Fukuyama and } \\
\text { Matousek (2017) }\end{array}$ & Japan & $\begin{array}{l}\text { Data Envelopment } \\
\text { Analysis }\end{array}$ & $\begin{array}{l}\text { There is a relationship between non-performing loans and the } \\
\text { performance of the banks. }\end{array}$ \\
\hline Akhigbe et. al. (2017a) & US & $\begin{array}{c}\text { Regression } \\
\text { Analysis }\end{array}$ & Transparency increases the performance of the banks. \\
\hline Boubakri et. al. (2017) & $\begin{array}{l}48 \text { different } \\
\text { countries }\end{array}$ & $\begin{array}{l}\text { Regression } \\
\text { Analysis }\end{array}$ & $\begin{array}{l}\text { Banks in collectivist societies performed better than the banks } \\
\text { in individualistic societies during the financial crisis. }\end{array}$ \\
\hline de Bandt et. al. (2017) & France & GMM & $\begin{array}{l}\text { Capital has a positive impact on the performance of French } \\
\text { banks. }\end{array}$ \\
\hline $\begin{array}{l}\text { Shaban and James } \\
(2017)\end{array}$ & Indonesia & $\begin{array}{c}\text { Regression } \\
\text { Analysis }\end{array}$ & $\begin{array}{l}\text { State banks have lower performance than the private and } \\
\text { foreign banks. }\end{array}$ \\
\hline Akhigbe et. al. (2017b) & US & $\begin{array}{l}\text { Stochastic Frontier } \\
\text { Analysis }\end{array}$ & $\begin{array}{l}\text { There is not an important difference between the performance } \\
\text { of public and private banks. }\end{array}$ \\
\hline $\begin{array}{l}\text { Psillaki and Mamatzakis } \\
\text { (2017) }\end{array}$ & $\begin{array}{c}10 \text { European } \\
\text { countries }\end{array}$ & $\begin{array}{l}\text { Stochastic Frontier } \\
\text { Analysis }\end{array}$ & $\begin{array}{l}\text { Structural reforms on business markets have a positive impact } \\
\text { on the performance of the banks. }\end{array}$ \\
\hline $\begin{array}{l}\text { Carvallo and Kasman } \\
\text { (2017) }\end{array}$ & $\begin{array}{l}\text { 19 Latin } \\
\text { American } \\
\text { countries }\end{array}$ & $\begin{array}{c}\text { Maximum } \\
\text { Likelihood } \\
\text { Estimator }\end{array}$ & $\begin{array}{l}\text { Country specific variables are important in the performance of } \\
\text { the banks. }\end{array}$ \\
\hline
\end{tabular}


There are many studies in the literature focusing on the determinants affecting the performance of the banks. Most of these studies underlined the importance of bank specific factors to increase the performance whereas some others emphasized the importance of country specific variables. In addition to this aspect, it can also be understood that different types of analysis methods were used in these studies, such as regression, logit, data envelopment analysis, and generalized method of moment approach. Therefore, it is identified that there is a need for a new study that focuses on the performance of the banking sector by using novel methods.

\section{Methodology}

\subsection{DEMATEL}

Decision Making Trial and Evaluation Laboratory (DEMATEL) method gives a contribution to solving the complex problems. It was developed in 1976 by the Institute of Geneva Battelle Memorial. The main advantage of DEMATEL method in comparison with others is that it is very helpful to evaluate the way and the power of the relationship between the variables (Chen, 2016). The steps of DEMATEL approach are demonstrated below (Bacudio et. al., 2016).

Step 1: Initial direct relation matrix is generated. This matrix is illustrated in Equation 1. The matrix is created based on the opinions of the experts.

$$
A_{k}=\left[\begin{array}{ccc}
0 & \cdots & a_{1 n k} \\
\vdots & \ddots & \vdots \\
a_{n 1 k} & \cdots & 0
\end{array}\right]
$$

Step 2: Initial influence matrix is calculated. In this step, the relationship among the elements can be identified.

Step 3: Direct relation matrix is normalized. In this process, Equation 2 is used. In this equation, the term "bij" takes values between 0 and 1 .

$$
B=\left[b_{i j}\right]_{n x n}=\frac{A}{\max \sum_{j=1}^{n} a_{i j}}
$$

Step 4: Total relation matrix is developed which is shown in Equation 3. In this equation, "C" represents total relation matrix and "I" gives information about identity matrix.

$$
C=\left[c_{i j}\right]_{n x n}=B(I-B)^{-1}
$$

Step 5: The prominence $(\mathrm{D}+\mathrm{E})$ and cause-effect $(\mathrm{D}-\mathrm{E})$ values are calculated. For this purpose, Equation 4 and 5 are taken into the consideration.

$$
D=\left[d_{i j}\right]_{n x 1}=\left[\sum_{j=1}^{n} c_{i j}\right]_{n x 1}
$$




$$
E=\left[e_{i j}\right]_{1 x n}=\left[\sum_{j=1}^{n} c_{i j}\right]_{1 x n}
$$

Step 6: Inner dependence matrix is defined. In this process, entries, which are less than the threshold value, are eliminated. The threshold value can be calculated by using Equation 6 .

$$
a=\frac{\sum_{j=1}^{n} \sum_{i=1}^{n} c_{i j}}{n^{2}}
$$

DEMATEL method was frequently used in the literature to evaluate the performance of different complex systems such as creating a model for sustainable consumption and production (Luthra et al., 2017); evaluating CRM partners (Büyüközkan et. al., 2017); defining critical success factors in emergency management (Zhou, 2017); evaluating the performance of supply chain for hospitals (Supeekit et al., 2016).

\subsection{Grey Relational Analysis (GRA)}

In grey relational analysis, the word "grey" refers to the condition between black and white. In this aspect, "black" means that there is no information whereas "white" shows that all information is available. In other words, grey demonstrates the complex and fuzzy situation. It can be said that grey relational analysis tries to select the best condition in various alternatives by considering the complex situation. This approach was developed by Julong Deng in 1982. It helps to make decision when the conditions are very complex (Deng, 1982). The steps of grey relational analysis are demonstrated below.

Step 1: Referential series and decision matrix are created. The details are shown in Equation 7. In this equation, $X_{-} 1$ (n) shows the value of alternative 1 and criterion $\mathrm{n}$.

$$
X_{i}=\left[\begin{array}{ccc}
X_{1}(1) & \cdots & X_{1}(n) \\
\vdots & \ddots & \vdots \\
X_{n}(1) & \cdots & X_{n}(n)
\end{array}\right]
$$

Step 2: The data set is normalized. The details of "larger is better" situation are given by Equation 8.

$$
X_{i}^{*}(j)=\frac{X_{i}(j)-\min _{j} X_{i}(j)}{\max _{j} X_{i}(j)-\min _{j} X_{i}(j)}
$$

If the condition is "smaller is better", Equation 9 can be used.

$$
X_{i}^{*}(j)=\frac{\max _{j} X_{i}(j)-X_{i}(j)}{\max _{j} X_{i}(j)-\min _{j} X_{i}(j)}
$$

After the normalization the matrix becomes:

$$
X_{i}{ }^{*}=\left[\begin{array}{ccc}
X_{1}{ }^{*}(1) & \cdots & X_{1}{ }^{*}(n) \\
\vdots & \ddots & \vdots \\
X_{n}{ }^{*}(1) & \cdots & X_{n}{ }^{*}(n)
\end{array}\right]
$$

Step 3: The distance of $\Delta_{-} 0 \mathrm{i}(\mathrm{j})$ is calculated. This value is equal to the difference between $\mathrm{X} 0 *$ and $\mathrm{Xi}^{*}$. Therefore, the distance is shown in Equation 11. 


$$
\Delta_{0 i}(j)=\left[\begin{array}{ccc}
\Delta_{01}(1) & \cdots & \Delta_{01}(n) \\
\vdots & \ddots & \vdots \\
\Delta_{0 m}(1) & \cdots & \Delta_{0 m}(n)
\end{array}\right]
$$

Step 4: Grey relational coefficient is calculated. The details are given by Equation 12. In this equation, "A" takes the value between 0 and 1 .

$$
r_{0 i}(j)=\frac{\Delta_{\min }+A \Delta_{\max }}{\Delta_{0 i}(j)+A \Delta_{\max }}
$$

Step 5: The degree of grey coefficient is calculated as shown in Equation 13. In this equation, "W" refers to the weight criteria. Subsequently, the alternative, which has the highest degree of grey coefficient, will be selected as the best alternative.

$$
\Gamma_{0 i}=\sum_{j=1}^{n}\left(W_{i}(j) X r_{0 i}(j)\right.
$$

Grey relational analysis is mainly used in the literature in order to select the best alternative. For example, GRA is applied to select the best supplier in the telecom industry of Iran (Ahmadi et al., 2017); to evaluate the suppliers for Turkish food manufacturing firms (Sar1 et al., 2016); to select the best stock in Istanbul Stock Exchange (Bayramoğlu and Hamzaçebi, 2016); to select the best web service (Li et al., 2016); to create a model for machine selection (Kabak and Dağdeviren, 2017).

\subsection{MOORA}

Multi-Objective Optimization on the basis of Ratio Analysis (MOORA) approach was developed by Brauers and Zavadskas in 2006. This method is used in order to evaluate complex alternatives. While making this evaluation by MOORA approach, some limitations should be taken into the consideration. The steps of this approach are given below (Brauers and Zavadskas, 2006).

Step 1: Different alternatives are defined by creating a decision matrix. The details of this matrix are shown in Equation 14. In this equation, $X_{i j}$ gives information about the value of the alternative $j$ and the criterion $i$.

$$
X_{i j}=\left[\begin{array}{ccc}
X_{11} & \cdots & X_{1 n} \\
\vdots & \ddots & \vdots \\
X_{m 1} & \cdots & X_{m n}
\end{array}\right]
$$

Step 2: The fuzzy matrix is normalized while considering vector normalization as shown in Equation 15. In this equation, the denominator shows all alternatives whereas the numerator explains the situation for alternative $j$ and criteria $i$.

$$
X_{i j}^{*}=\frac{X_{i j}}{\sqrt{\sum_{j=1}^{m} X^{2}{ }_{i j}}}
$$

Step 3: Positive and negative effects are analyzed. In this process, a criterion takes positive values in the case of performance increase whereas negative values are considered in opposite aspect: 


$$
Y_{i}=\sum_{j=1}^{h} X_{i j}^{*}-\sum_{j=h+1}^{n} X_{i j}^{*}
$$

Step 4: Weighted results are identified as shown in Equation 17.

$$
Y_{i}^{*}=\sum_{j=1}^{h} W_{j} X_{i j}^{*}-\sum_{j=h+1}^{n} W_{j} X_{i j}^{*}
$$

Step 5: The results are ranked, and the best alternative can be chosen.

MOORA method was used in many different studies in the literature to analyze several complex decision-making problems such as the sector selection of the students of industrial engineering departments in Turkey (Akkaya et al., 2015); evaluation of the performance of airline companies (Dinçer et. al., 2017); selection of the best logistic provider in the plastic industry (Mavi et al., 2017); selection of the best car for car renting firms (Bircan et al., 2017).

\section{An Application on Turkish Banking Sector}

\subsection{Data and Variables}

In this study, an integrated multi-criteria decision-making approach has been applied for measuring the performance of Turkish deposit banks. For this purpose, two integrated approaches entitled DEMATEL-MOORA and DEMATEL-GRA are constructed for the comparative decision-making.

Two different kinds of data have been used to analyze the criteria and alternatives. The data for the criteria has been obtained from the ScienceDirect (http://www.sciencedirect.com); while the data on alternatives (i.e. banks) is obtained from the Banks Association of Turkey. 23 deposit banks in Turkey, called as alternatives in the analysis, have been considered for ranking the performance. According to the ownership, first three banks are state-owned banks, A4 to A11 are defined as private banks while others are foreign banks.

For the analysis, a set of variables extracted from the financial statements of the banks in 2015 has been defined and 13 criteria have been selected with the defined keywords based on the literature. Table 4 illustrates the selected criteria and keywords for the decisionmaking analysis.

\subsection{Analysis Results}

The analysis consists of two main stages. The first stage is to determine the weights of the criteria with the DEMATEL technique. Initially, the related keywords have been defined to appoint the linguistic evaluation for each criterion. Thus, a knowledge extractionbased assessment of the criteria has been provided by using the text mining results attained from selected keywords. For this purpose, a query that gives the abstracts of articles that are published after 2007 and have the keywords "bank" or "banking" in their title or abstract or keyword sections has been executed on ScienceDirect. Abstracts of 6.898 studies have been obtained from this query and they have been merged into a single text file. A text mining process containing transformation to lower case, tokenization, filtering the stopwords steps 
on this text file has been utilized. By using regular expressions, the frequency of keywords in Table 4 has been taken out of all results of the text-mining process.

Table 4: Variables Used in the Analysis

\begin{tabular}{|c|c|c|c|c|}
\hline Dimensions & Criteria & Definition & Keywords & Supporting Literature \\
\hline \multirow{2}{*}{$\begin{array}{l}\text { Capital } \\
\text { Ratios }\end{array}$} & $\mathrm{C} 1$ & $\begin{array}{l}\text { Shareholders' Equity / ((Capital to be } \\
\text { Employed to credit }+ \text { market }+ \\
\text { operational risk)*12.5)*100 }\end{array}$ & adequacy ratio & $\begin{array}{l}\text { Boubakri et. al. (2017), Sun et. } \\
\text { al. (2017), de Bandt et. al. } \\
\text { (2017), Shaban and James } \\
\text { (2017), Cornett et al. (2016), } \\
\text { Bitar et. al. (2016) }\end{array}$ \\
\hline & $\mathrm{C} 2$ & $\begin{array}{c}\text { On Balance-sheet FC Position / } \\
\text { Shareholders' Equity }\end{array}$ & $\begin{array}{l}\text { foreign currency } \\
\text { (FC) position, } \\
\text { balance-sheet } \\
\text { position }\end{array}$ & $\begin{array}{l}\text { Sun and Chang (2011), } \\
\text { Davydenko (2010), Kutan et. al. } \\
(2012)\end{array}$ \\
\hline \multirow{5}{*}{$\begin{array}{l}\text { Asset } \\
\text { Quality }\end{array}$} & $\mathrm{C} 3$ & Financial Assets (Net) / Total Assets & financial asset & $\begin{array}{l}\text { Berger et. al. (2010), Seyrek and } \\
\text { Ata (2010), Aktaş and Kırgın } \\
(2007)\end{array}$ \\
\hline & $\mathrm{C} 4$ & $\begin{array}{l}\text { Total Loans and Receivables* / Total } \\
\text { Assets }\end{array}$ & total loans & $\begin{array}{l}\text { Akhigbe et. al. (2017b), Sun et. } \\
\text { al. (2017), Shaban and James } \\
\text { (2017), Bian and Deng (2017), } \\
\text { Cai et. al. (2016) }\end{array}$ \\
\hline & C5 & $\begin{array}{l}\text { Loans under follow-up (gross) / Total } \\
\text { Loans and Receivables }\end{array}$ & $\begin{array}{l}\text { non-performing } \\
\text { loans (NPL) }\end{array}$ & $\begin{array}{l}\text { Boubakri et. al. (2017), Akhigbe } \\
\text { et. al. (2017b), Fukuyama and } \\
\text { Matousek (2017), Psillaki and } \\
\text { Mamatzakis (2017), Bitar et. al. } \\
\text { (2016) }\end{array}$ \\
\hline & C6 & Permanent Assets / Total Assets & $\begin{array}{l}\text { permanent assets, } \\
\text { fixed assets, } \\
\text { tangible asset, } \\
\text { intangible asset }\end{array}$ & $\begin{array}{l}\text { Yüksel et. al. (2015), Çinko and } \\
\text { Avc1 (2008) }\end{array}$ \\
\hline & $\mathrm{C} 7$ & Liquid Assets / Total Assets & liquid assets & $\begin{array}{l}\text { Boubakri et. al. (2017), Sun et. } \\
\text { al. (2017), Mamatzakis and } \\
\text { Bermpei (2016), Salim et. al. } \\
\text { (2016) }\end{array}$ \\
\hline \multirow{2}{*}{ Profitability } & $\mathrm{C} 8$ & Net Profit (Losses) / Total Assets & $\begin{array}{l}\text { net profit, return on } \\
\text { asset (ROA) }\end{array}$ & $\begin{array}{l}\text { Boubakri et. al. (2017), Scott et. } \\
\text { al. (2017), de Bandt et. al. } \\
\text { (2017), Cai et. al. (2016) }\end{array}$ \\
\hline & C9 & $\begin{array}{l}\text { Net Profit (Losses) / Total } \\
\text { Shareholders' Equity }\end{array}$ & $\begin{array}{l}\text { return on equity } \\
\quad(\mathrm{ROE})\end{array}$ & $\begin{array}{l}\text { Boubakri et. al. (2017), Scott et. } \\
\text { al. (2017), de Bandt et. al. } \\
(2017)\end{array}$ \\
\hline \multirow{4}{*}{$\begin{array}{l}\text { Income and } \\
\text { Expense } \\
\text { Structure }\end{array}$} & $\mathrm{C} 10$ & $\begin{array}{l}\text { Net Interest Income After Specific } \\
\text { Provisions / Total Assets }\end{array}$ & interest income & $\begin{array}{l}\text { Fukuyama and Matousek } \\
(2017), \quad \text { Mamatzakis and } \\
\text { Bermpei (2016) }\end{array}$ \\
\hline & $\mathrm{C} 11$ & $\begin{array}{c}\text { Non-Interest Income (Net) / Total } \\
\text { Assets }\end{array}$ & non-interest income & $\begin{array}{l}\text { Akhigbe et. al. (2017b), Sun et. } \\
\text { al. (2017), Bian and Deng } \\
\text { (2017), Saghi-Zedek (2016) }\end{array}$ \\
\hline & $\mathrm{C} 12$ & $\begin{array}{l}\text { Other Operating Expenses / Total } \\
\text { Operating Income }\end{array}$ & $\begin{array}{l}\text { operating expense, } \\
\text { operating cost, fixed } \\
\text { cost, overhead cost, } \\
\text { non-interest cost }\end{array}$ & $\begin{array}{l}\text { Scott et. al. (2017), Sun et. al. } \\
\text { (2017), Gerhardt and Vander } \\
\text { Vennet (2016) }\end{array}$ \\
\hline & $\mathrm{C} 13$ & Interest Expense / Total Assets & $\begin{array}{l}\text { interest expense, } \\
\text { interest risk, interest } \\
\text { cost }\end{array}$ & $\begin{array}{l}\text { Gerhardt and Vander Vennet } \\
\text { (2016), Dong et. al. (2016) }\end{array}$ \\
\hline
\end{tabular}


The frequency results have been utilized in the pairwise comparison matrices and accordingly the comparison results have been transformed to the five-point linguistic scales to build the direct relationship matrix and to evaluate the relative importance of each criterion with the DEMATEL method (see Tablela, in appendix). Then the direct relation matrix (see Table 2a, in appendix) is normalized and the total relation matrix is constructed (Table 5) which shows the direct/indirect relation of the criteria.

\section{Table 5: Total relation matrix}

\begin{tabular}{|l|l|l|l|l|l|l|l|l|l|l|l|l|l|}
\hline & C1 & C2 & C3 & C4 & C5 & C6 & C7 & C8 & C9 & C10 & C11 & C12 & C13 \\
\hline C1 & 0,000 & 0,000 & 0,000 & 0,000 & 0,000 & 0,063 & 0,000 & 0,000 & 0,000 & 0,000 & 0,000 & 0,000 & 0,000 \\
\hline C2 & 0,063 & 0,000 & 0,063 & 0,137 & 0,000 & 0,219 & 0,063 & 0,063 & 0,063 & 0,000 & 0,000 & 0,000 & 0,133 \\
\hline C3 & 0,000 & 0,000 & 0,000 & 0,000 & 0,000 & 0,063 & 0,000 & 0,000 & 0,000 & 0,000 & 0,000 & 0,000 & 0,000 \\
\hline C4 & 0,000 & 0,000 & 0,000 & 0,000 & 0,000 & 0,000 & 0,000 & 0,000 & 0,000 & 0,000 & 0,000 & 0,000 & 0,000 \\
\hline C5 & 0,063 & 0,000 & 0,063 & 0,137 & 0,000 & 0,219 & 0,063 & 0,063 & 0,063 & 0,000 & 0,000 & 0,000 & 0,133 \\
\hline C6 & 0,000 & 0,000 & 0,000 & 0,000 & 0,000 & 0,000 & 0,000 & 0,000 & 0,000 & 0,000 & 0,000 & 0,000 & 0,000 \\
\hline C7 & 0,000 & 0,000 & 0,000 & 0,063 & 0,000 & 0,063 & 0,000 & 0,000 & 0,000 & 0,000 & 0,000 & 0,000 & 0,000 \\
\hline C8 & 0,000 & 0,000 & 0,000 & 0,063 & 0,000 & 0,129 & 0,000 & 0,000 & 0,000 & 0,000 & 0,000 & 0,000 & 0,063 \\
\hline C9 & 0,000 & 0,000 & 0,000 & 0,063 & 0,000 & 0,066 & 0,000 & 0,000 & 0,000 & 0,000 & 0,000 & 0,000 & 0,063 \\
\hline C10 & 0,063 & 0,000 & 0,129 & 0,203 & 0,000 & 0,294 & 0,063 & 0,063 & 0,063 & 0,000 & 0,000 & 0,063 & 0,137 \\
\hline C11 & 0,063 & 0,000 & 0,063 & 0,133 & 0,000 & 0,207 & 0,063 & 0,000 & 0,063 & 0,000 & 0,000 & 0,000 & 0,066 \\
\hline C12 & 0,000 & 0,000 & 0,063 & 0,063 & 0,000 & 0,133 & 0,000 & 0,000 & 0,000 & 0,000 & 0,000 & 0,000 & 0,063 \\
\hline C13 & 0,000 & 0,000 & 0,000 & 0,000 & 0,000 & 0,063 & 0,000 & 0,000 & 0,000 & 0,000 & 0,000 & 0,000 & 0,000 \\
\hline
\end{tabular}

Table 6 demonstrate the consecutive steps for the weights of the criteria with the DEMATEL approach. In the last step of the first stage, the impact degrees of the criteria $(D+E)$ and the cause and effect relationship (D-E) have been computed as seen in Table 8.

\section{Table 6: Impact degrees and weights of the criteria}

\begin{tabular}{|c|c|c|c|c|l|}
\hline & $\mathbf{D}$ & $\mathbf{E}$ & $\mathbf{( D + E )}$ & $\mathbf{( D - E )}$ & Weights \\
\hline $\mathbf{C 1}$ & 0,0625 & 0,2500 & 0,3125 & $-0,1875$ & 0,035 \\
\hline C2 & 0,8013 & 0,0000 & 0,8013 & 0,8013 & 0,091 \\
\hline C3 & 0,0625 & 0,378906 & 0,4414 & $-0,3164$ & 0,050 \\
\hline C4 & 0,0000 & 0,859375 & 0,8594 & $-0,8594$ & 0,097 \\
\hline C5 & 0,8013 & 0 & 0,8013 & 0,8013 & 0,091 \\
\hline C6 & 0,0000 & 1,517822 & 1,5178 & $-1,5178$ & 0,172 \\
\hline C7 & 0,1250 & 0,25 & 0,3750 & $-0,1250$ & 0,042 \\
\hline C8 & 0,2539 & 0,1875 & 0,4414 & 0,0664 & 0,050 \\
\hline C9 & 0,1914 & 0,25 & 0,4414 & $-0,0586$ & 0,050 \\
\hline C10 & 1,0752 & 0 & 1,0752 & 1,0752 & 0,122 \\
\hline C11 & 0,6565 & 0 & 0,6565 & 0,6565 & 0,074 \\
\hline C12 & 0,3203 & 0,0625 & 0,3828 & 0,2578 & 0,043 \\
\hline C13 & 0,0625 & 0,65625 & 0,7188 & $-0,5938$ & 0,081 \\
\hline
\end{tabular}

Weights of the criteria have been computed by using the normalized values of the impact degrees of the criteria. Table 6 illustrates that C6 is the most important variable for the banking performance while $\mathrm{C} 1$ is the worst degree. 
Next phase continues with the GRA method for ranking the alternative banks. The dataset for the alternatives and criteria as well as the reference sequence is given in Table $3 \mathrm{a}$ in appendix. The reference sequences for the variables have been appointed in the constraints of $\mathrm{C} 5, \mathrm{C} 12$, and $\mathrm{C} 13$ should be minimized while the others should be maximized (see Table 3a). In the following steps of GRA, the normalized values and deviation sequences have been employed to measure the grey relational coefficients (see Table $4 \mathrm{a}$, in the appendix). The last step of the GRA method is to calculate the weighted coefficients for ranking alternatives. For this purpose, Grey relational grade has been calculated by multiplying the weights of the criteria and the values of the coefficients. Table 7 represents the weighted scores defining the grey relational grade.

Table 7: Grey Relational Grade and Ranking Results

\begin{tabular}{|l|c|c|}
\hline Alternatives & Grey Relational Grade & Ranking \\
\hline A1 & 0,515 & 14 \\
\hline A2 & 0,482 & 18 \\
\hline A3 & 0,481 & 20 \\
\hline A4 & 0,479 & 21 \\
\hline A5 & 0,492 & 16 \\
\hline A6 & 0,541 & 10 \\
\hline A7 & 0,516 & 13 \\
\hline A8 & 0,614 & 2 \\
\hline A9 & 0,555 & 7 \\
\hline A10 & 0,518 & 12 \\
\hline A11 & 0,481 & 19 \\
\hline A12 & 0,547 & 8 \\
\hline A13 & 0,612 & 3 \\
\hline A14 & 0,559 & 6 \\
\hline A15 & 0,580 & 4 \\
\hline A16 & 0,518 & 11 \\
\hline A17 & 0,694 & 1 \\
\hline A18 & 0,506 & 15 \\
\hline A19 & 0,543 & 9 \\
\hline A20 & 0,445 & 23 \\
\hline A21 & 0,564 & 5 \\
\hline A22 & 0,466 & 22 \\
\hline A23 & 0,487 & 17 \\
\hline
\end{tabular}

According to the Table 7, A17 has the best performance results in banking sector while A20 is the worst seat in the banks. It is understood that foreign banks have better performance while comparing with other types of the banks.

Another integrated multi-criteria decision-making approach is the DEMATEL-MOORA. This approach is divided into two main sections. In the first stage, the DEMATEL method has been adapted in the same steps in the second integrated methodology. That is why same weights have been considered in the remaining steps.

Proposed method with the MOORA is defined in the following steps. The initial step of the MOORA method is to construct the decision matrix. After that, the dimensionless number has been calculated (see Table 5a, in appendix). Same minimization and maximization 
assumptions regarding the criteria have been employed for calculating the benefit and cost criteria. Accordingly, weighted scores and final ranking results are obtained (see Table 7).

Table 8: Benefit and Cost Criteria and Ranking Results

\begin{tabular}{|l|c|c|c|c|}
\hline Alternatives & Benefit Criteria & Cost Criteria & Weighted Scores & Ranking \\
\hline A1 & 0,166 & 0,021 & 0,145 & 5 \\
\hline A2 & 0,143 & 0,030 & 0,113 & 18 \\
\hline A3 & 0,143 & 0,035 & 0,109 & 19 \\
\hline A4 & 0,160 & 0,024 & 0,135 & 7 \\
\hline A5 & 0,165 & 0,035 & 0,130 & 11 \\
\hline A6 & 0,125 & 0,025 & 0,100 & 20 \\
\hline A7 & 0,172 & 0,049 & 0,123 & 13 \\
\hline A8 & 0,141 & 0,028 & 0,114 & 17 \\
\hline A9 & 0,158 & 0,028 & 0,130 & 10 \\
\hline A10 & 0,173 & 0,025 & 0,149 & 4 \\
\hline A11 & 0,154 & 0,035 & 0,119 & 15 \\
\hline A12 & 0,160 & 0,042 & 0,118 & 16 \\
\hline A13 & 0,165 & 0,013 & 0,153 & 3 \\
\hline A14 & 0,152 & 0,031 & 0,121 & 14 \\
\hline A15 & 0,185 & 0,026 & 0,159 & 2 \\
\hline A16 & 0,187 & 0,043 & 0,144 & 6 \\
\hline A17 & 0,180 & 0,012 & 0,169 & 1 \\
\hline A18 & 0,184 & 0,049 & 0,135 & 8 \\
\hline A19 & 0,138 & 0,049 & 0,089 & 23 \\
\hline A20 & 0,135 & 0,039 & 0,096 & 21 \\
\hline A21 & 0,161 & 0,031 & 0,130 & 12 \\
\hline A22 & 0,141 & 0,051 & 0,090 & 22 \\
\hline A23 & 0,160 & 0,027 & 0,133 & 9 \\
\hline
\end{tabular}

Comparative analysis results of two different integrated models can be seen in table 9. Both models have same ranking results for A2, A7, A13, A17, and A22. Additionally, the integrated models have also ranked the same bank (A17) in the first place. These results demonstrate that proposed models are widely coherent to find out the best performing bank. In addition to this situation, because computation process of these methods differs from each other, some of the results will be different as well. 
Table 9: Comparative analysis results of the integrated models

\begin{tabular}{|l|c|c|c|c|}
\hline & \multicolumn{2}{|c|}{ DEMATEL-GRA } & \multicolumn{2}{c|}{ DEMATEL-MOORA } \\
\hline Alternatives & Scores & Ranking & Scores & Ranking \\
\hline A1 & 0,515 & 14 & 0,145 & 5 \\
\hline A2 & 0,482 & 18 & 0,113 & 18 \\
\hline A3 & 0,481 & 20 & 0,109 & 19 \\
\hline A4 & 0,479 & 21 & 0,135 & 7 \\
\hline A5 & 0,492 & 16 & 0,130 & 11 \\
\hline A6 & 0,541 & 10 & 0,100 & 20 \\
\hline A7 & 0,516 & 13 & 0,123 & 13 \\
\hline A8 & 0,614 & 2 & 0,114 & 17 \\
\hline A9 & 0,555 & 7 & 0,130 & 10 \\
\hline A10 & 0,518 & 12 & 0,149 & 4 \\
\hline A11 & 0,481 & 19 & 0,119 & 15 \\
\hline A12 & 0,547 & 8 & 0,118 & 16 \\
\hline A13 & 0,612 & 3 & 0,153 & 3 \\
\hline A14 & 0,559 & 6 & 0,121 & 14 \\
\hline A15 & 0,580 & 4 & 0,159 & 2 \\
\hline A16 & 0,518 & 11 & 0,144 & 6 \\
\hline A17 & 0,694 & 1 & 0,169 & 1 \\
\hline A18 & 0,506 & 15 & 0,135 & 8 \\
\hline A19 & 0,543 & 9 & 0,089 & 23 \\
\hline A20 & 0,445 & 23 & 0,096 & 21 \\
\hline A21 & 0,564 & 5 & 0,130 & 12 \\
\hline A22 & 0,466 & 22 & 0,090 & 22 \\
\hline A23 & 0,487 & 17 & 0,133 & 9 \\
\hline
\end{tabular}

\section{Discussion and Conclusion}

Performance measurement of the banking sector remains a prominent issue in the competitive financial markets. There are several methods and variables to evaluate the banks and make a right decision on the investment. By the way, some debates consider the lack of the multidimensional effects while many set aside the knowledge extraction-based decision making approaches. That is the reason why data mining methods recently arise as important techniques that should be combined with the different kinds of decision-making methods.

Financial decision-making needs for the multidimensional comparison including the interdependencies together with text mining approach whereas the most studies in finance commonly do not care the different effects for the investment decisions expect the financial data. Financial topic with text mining is still one of outstanding issues in knowledge extraction-based modeling. Thus, fuzzy based modeling using the integrated text mining method could be useful for further studies.

The novelties of the study are to find out the relative importance of the financial criteria using text mining with DEMATEL method to propose integrated models and to provide comparative results to discuss the model results. Accordingly, ScienceDirect platform is considered to extract the frequencies of the selected keywords and DEMATEL-GRA and DEMATEL-MOORA methods are selected for the integrated models.

The results demonstrate that both integrated models could provide the best rank to measure the financial performance of banking sector and the text mining results could be adapted 
properly in the multidimensional decision-making. Finally, the method could be extended by using different kinds of multi-criteria decision-making models and several data mining processes such as web mining could be added for the comprehensive analysis. Another important conclusion of this study is that foreign banks have better performance than state and private banks.

\section{References}

Ahmadi, H. B., Petrudi, S. H. H., \& Wang, X. (2016). Integrating sustainability into supplier selection with analytical hierarchy process and improved grey relational analysis: a case of telecom industry. The International Journal of Advanced Manufacturing Technology, 9(90), 2413-2427.

Akhigbe, A., McNulty, J. E., \& Stevenson, B. A. (2017a). Additional evidence on transparency and bank financial performance. Review of Financial Economics, 32, 1-6. doi:10.1016/j.rfe.2016.09.001

Akhigbe, A., McNulty, J. E., \& Stevenson, B. A. (2017b). Does the form of ownership affect firm performance? Evidence from US bank profit efficiency before and during the financial crisis. The Quarterly Review of Economics and Finance, 64, 120-129. doi:10.1016/j.qref.2016.07.015

Akkaya, G., Turanoğlu, B., \& Öztaş, S. (2015). An integrated fuzzy AHP and fuzzy MOORA approach to the problem of industrial engineering sector choosing. Expert Systems with Applications, 42(24), 9565-9573. doi:10.1016/j.eswa.2015.07.061

Aktaş, H., \& Kargın, M. (2007). Türk bankacılık sektöründeki yabancı ve ulusal bankaların finansal oranlar açısından karşılaştırılması. Yönetim ve Ekonomi, 14(2), 31-45.

Ali, M., \& Azmi, W. (2016). Religion in the boardroom and its impact on Islamic banks' performance. Review of Financial Economics, 31, 83-88. doi:10.1016/j.rfe.2016.08.001

Bacudio, L. R., Benjamin, M. F. D., Eusebio, R. C. P., Holaysan, S. A. K., Promentilla, M. A. B., Yu, K. D. S., \& Aviso, K. B. (2016). Analyzing barriers to implementing industrial symbiosis networks using DEMATEL. Sustainable Production and Consumption, 7, 57-65. doi:10.1016/j.spc.2016.03.001

Bayramoglu, M. F., \& Hamzacebi, C. (2016). Stock Selection Based on Fundamental Analysis Approach by Grey Relational Analysis: A Case of Turkey. International Journal of Economics and Finance, 8(7), 178-184. doi:10.5539/ijef.v8n7p178

Berger, A. N., Hasan, I., \& Zhou, M. (2010). The effects of focus versus diversification on bank performance: Evidence from Chinese banks. Journal of Banking \& Finance, 34(7), 14171435. doi:10.1016/j.jbankfin.2010.01.010

Bian, W., \& Deng, C. (2017). Ownership dispersion and bank performance: Evidence from China. Finance Research Letters. doi:10.1016/j.frl.2016.12.030

Bircan, H., ARSLAN, R., \& Eleroğlu, H. (2017, February). AHS İle Ağırlıklandırılmış MOORA ve VIKOR Yöntemiyle Araç Seçimi; Rent a Car Firması Uygulaması. In ICPESS (International Congress on Politic, Economic and Social Studies) (No. 2). 
Bitar, M., Saad, W., \& Benlemlih, M. (2016). Bank risk and performance in the MENA region: The importance of capital requirements. Economic Systems, 40(3), 398-421. doi:10.1016/j.ecosys.2015.12.001

Boubakri, N., Mirzaei, A., \& Samet, A. (2017). National culture and bank performance: Evidence from the recent financial crisis. Journal of Financial Stability, 29, 36-56. doi:10.1016/j.jfs.2017.02.003

Brauers, W.K.M. and Zavadskas, E.K. (2006). The MOORA Method and Its Application to Privatization in a Transition Economy. Control and Cybernetics, 35, 445-469.

Büyüközkan, G., Güleryüz, S., \& Karpak, B. (2017). A new combined IF-DEMATEL and IF-ANP approach for CRM partner evaluation. International Journal of Production Economics, 191, 194-206. doi:10.1016/j.ijpe.2017.05.012

Cai, W., Xu, F., \& Zeng, C. (2016). Geographical diversification and bank performance: Evidence from China. Economics Letters, 147, 96-98. doi:10.1016/j.econlet.2016.08.022

Carvallo, O., \& Kasman, A. (2017). Convergence in bank performance: Evidence from Latin American banking. The North American Journal of Economics and Finance, 39, 127-142. doi:10.1016/j.najef.2016.08.002

Chai, B. B. H., Tan, P. S., \& Goh, T. S. (2016). Banking services that influence the bank performance. Procedia-Social and Behavioral Sciences, 224, 401-407. doi:10.1016/j.sbspro.2016.05.405

Chen, I. S. (2016). A combined MCDM model based on DEMATEL and ANP for the selection of airline service quality improvement criteria: A study based on the Taiwanese airline industry. Journal of Air Transport Management, 57, 7-18. doi:10.1016/j.jairtraman.2016.07.004

Cornett, M. M., Erhemjamts, O., \& Tehranian, H. (2016). Greed or good deeds: An examination of the relation between corporate social responsibility and the financial performance of US commercial banks around the financial crisis. Journal of Banking \& Finance, 70, 137-159. doi:10.1016/j.jbankfin.2016.04.024

Çinko, M., \& Avc1, E. (2008). CAMELS Derecelendirme Sistemi ve Türk Ticari Bankacılık Sektöründe Başarısızlık Tahmini. BDDK Bankacılık ve Finansal Piyasalar Dergisi, 2(2), 2548 .

Davydenko, A. (2010). Determinants of bank profitability in Ukraine. Undergraduate Economic Review, 7(1), Article 2.

de Bandt, O., Camara, B., Maitre, A., \& Pessarossi, P. (2017). Optimal capital, regulatory requirements and bank performance in times of crisis: Evidence from France. Journal of Financial Stability

Gerhardt, M., \& Vander Vennet, R. (2016). Bank bailouts in Europe and bank performance. Finance Research Letters.

Deng, J. (1982). Control problems of grey systems. Systems \& Control Letters, 1(5), 288-294. doi:10.1016/S0167-6911(82)80025-X

Dinçer, H., Hacıoğlu, Ü., \& Yüksel, S. (2017). Balanced scorecard based performance measurement of European airlines using a hybrid multi criteria decision making approach under the fuzzy environment. Journal of Air Transport Management, 63, 17-33. doi:10.1016/j.jairtraman.2017.05.005 
Dong, Y., Firth, M., Hou, W., \& Yang, W. (2016). Evaluating the performance of Chinese commercial banks: A comparative analysis of different types of banks. European Journal of Operational Research, 252(1), 280-295. doi:10.1016/j.ejor.2015.12.038

Fukuyama, H., \& Matousek, R. (2017). Modeling bank performance: A network DEA approach. European Journal of Operational Research, 259(2), 721-732. doi:10.1016/j.ejor.2016.10.044

Ghosh, A. (2016). Banking sector globalization and bank performance: A comparative analysis of low income countries with emerging markets and advanced economies. Review of Development Finance, 6(1), 58-70. doi:10.1016/j.rdf.2016.05.003

Jawadi, F., Jawadi, N., Cheffou, A. I., Ameur, H. B., \& Louhichi, W. (2017). Modelling the effect of the geographical environment on Islamic banking performance: A panel quantile regression analysis. Economic Modelling. doi:10.1016/j.econmod.2017.01.018

Juo, J. C., Fu, T. T., Yu, M. M., \& Lin, Y. H. (2016). Non-radial profit performance: An application to Taiwanese banks. Omega, 65, 111-121. doi:10.1016/j.omega.2016.01.003

Kabak, M., \& Dağdeviren, M. (2017). A hybrid approach based on ANP and grey relational analysis for machine selection. Tehnički vjesnik, 24(Supplement 1), 109-118.

King, T., Srivastav, A., \& Williams, J. (2016). What's in an education? Implications of CEO education for bank performance. Journal of Corporate Finance, 37, 287-308. doi:10.1016/j.jcorpfin.2016.01.003

Kutan, A. M., Ozsoz, E., \& Rengifo, E. W. (2012). Cross-sectional determinants of bank performance under deposit dollarization in emerging markets. Emerging Markets Review, 13(4), 478-492. doi:10.1016/j.ememar.2012.07.003

Li, W., Li, Y., \& Tang, C. (2016). Web Service Selection Method Based on Grey Relational Analysis. International Journal of Hybrid Information Technology, 9(3), 117-124. doi:10.14257/ijhit.2016.9.3.11

Luthra, S., Govindan, K., \& Mangla, S. K. (2017). Structural model for sustainable consumption and production adoption-A grey-DEMATEL based approach. Resources, Conservation and Recycling, 125, 198-207. doi:10.1016/j.resconrec.2017.02.018

Mamatzakis, E., \& Bermpei, T. (2016). What is the effect of unconventional monetary policy on bank performance?. Journal of International Money and Finance, 67, 239-263. doi:10.1016/j.jimonfin.2016.05.005

Mavi, R. K., Goh, M., \& Zarbakhshnia, N. (2017). Sustainable third-party reverse logistic provider selection with fuzzy SWARA and fuzzy MOORA in plastic industry. The International Journal of Advanced Manufacturing Technology, 1-18. doi:10.1007/s00170-016-9880-x

Meles, A., Porzio, C., Sampagnaro, G., \& Verdoliva, V. (2016). The impact of the intellectual capital efficiency on commercial banks performance: Evidence from the US. Journal of Multinational Financial Management, 36, 64-74. doi:10.1016/j.mulfin.2016.04.003

Mirzaei, A., \& Moore, T. (2016). Banking performance and industry growth in an oil-rich economy: Evidence from Qatar. The Quarterly Review of Economics and Finance, 60, 58-69. doi:10.1016/j.qref.2015.06.001

Nagano, M. (2016). The bank-firm relationship during economic transition: The impacts on bank performance in emerging economies. Emerging Markets Review, 28, 117-139. doi:10.1016/j.ememar.2016.08.005 
Oktar, S., \& Yüksel, S. (2016). Bankalarin Türev Ürün Kullanimini Etkileyen Faktörler: Mars Yöntemi ile Bir Inceleme/Determinants of the Use Derivatives in Banking: An Analysis with MARS Model. Finans Politik \& Ekonomik Yorumlar, 53(620), 31-46.

Psillaki, M., \& Mamatzakis, E. (2017). What drives bank performance in transitions economies? The impact of reforms and regulations. Research in International Business and Finance, 39, 578 594. doi:10.1016/j.ribaf.2016.09.010

Salim, R., Arjomandi, A., \& Seufert, J. H. (2016). Does corporate governance affect Australian banks' performance?. Journal of International Financial Markets, Institutions and Money, 43, 113-125. doi:10.1016/j.intfin.2016.04.006

Saghi-Zedek, N. (2016). Product diversification and bank performance: does ownership structure matter?. Journal of Banking \& Finance, 71, 154-167. doi:10.1016/j.jbankfin.2016.05.003

Sarı, T., Baynal, K., \& Ergül, Ö. (2016). Supplier Selection with Grey Relational Analysis. International Journal of Emerging Research in Management \& Technology, 5, 61-70.

Scott, S. V., Van Reenen, J., \& Zachariadis, M. (2017). The long-term effect of digital innovation on bank performance: an empirical study of SWIFT adoption in financial services. Research Policy, 46(5), 984-1004. doi:10.1016/j.respol.2017.03.010

Seyrek, İ. H., \& Ata, H. A. (2010). Veri Zarflama Analizi ve Veri Madenciliği ile Mevduat Bankalarında Etkinlik Ölçümü. Journal of BRSA Banking \& Financial Markets, 4(2), 67-84.

Shaban, M., \& James, G. A. (2017). The effects of ownership change on bank performance and risk exposure: Evidence from Indonesia. Journal of Banking \& Finance.

Sun, L., \& Chang, T. P. (2011). A comprehensive analysis of the effects of risk measures on bank efficiency: Evidence from emerging Asian countries. Journal of Banking \& Finance, 35(7), 1727-1735. doi:10.1016/j.jbankfin.2010.11.017

Sun, P. H., Mohamad, S., \& Ariff, M. (2017). Determinants driving bank performance: A comparison of two types of banks in the OIC. Pacific-Basin Finance Journal, 42, 193-203. doi:10.1016/j.pacfin.2016.02.007

Supeekit, T., Somboonwiwat, T., \& Kritchanchai, D. (2016). DEMATEL-modified ANP to evaluate internal hospital supply chain performance. Computers \& Industrial Engineering, 102, 318 330. doi:10.1016/j.cie.2016.07.019

Yüksel, S. (2017). Determinants of the Credit Risk in Developing Countries After Economic Crisis: A Case of Turkish Banking Sector. In Global Financial Crisis and Its Ramifications on Capital Markets (pp. 401-415). Springer International Publishing. doi:10.1007/978-3-31947021-4_28

Yüksel, S., Dincer, H., \& Hacioglu, U. (2015). CAMELS-based Determinants for the Credit Rating of Turkish Deposit Banks. International Journal of Finance \& Banking Studies, 4(4), 1-17.

Yüksel, S., \& Zengin, S. (2017). Influencing Factors of Net Interest Margin in Turkish Banking Sector. International Journal of Economics and Financial Issues, 7(1), 178-191.

Zhou, X., Shi, Y., Deng, X., \& Deng, Y. (2017). D-DEMATEL: A new method to identify critical success factors in emergency management. Safety science, 91, 93-104. doi:10.1016/j.ssci.2016.06.014 


\section{APPENDIX A}

Table 1a: Direct relationship matrix

\begin{tabular}{|l|c|c|c|c|c|c|c|c|c|c|c|c|c|}
\hline & C1 & C2 & C3 & C4 & C5 & C6 & C7 & C8 & C9 & C10 & C11 & C12 & C13 \\
\hline C1 & 0 & 0 & 0 & 0 & 0 & 1 & 0 & 0 & 0 & 0 & 0 & 0 & 0 \\
\hline C2 & 1 & 0 & 1 & 2 & 0 & 3 & 1 & 1 & 1 & 0 & 0 & 0 & 2 \\
\hline C3 & 0 & 0 & 0 & 0 & 0 & 1 & 0 & 0 & 0 & 0 & 0 & 0 & 0 \\
\hline C4 & 0 & 0 & 0 & 0 & 0 & 0 & 0 & 0 & 0 & 0 & 0 & 0 & 0 \\
\hline C5 & 1 & 0 & 1 & 2 & 0 & 3 & 1 & 1 & 1 & 0 & 0 & 0 & 2 \\
\hline C6 & 0 & 0 & 0 & 0 & 0 & 0 & 0 & 0 & 0 & 0 & 0 & 0 & 0 \\
\hline C7 & 0 & 0 & 0 & 1 & 0 & 1 & 0 & 0 & 0 & 0 & 0 & 0 & 0 \\
\hline C8 & 0 & 0 & 0 & 1 & 0 & 2 & 0 & 0 & 0 & 0 & 0 & 0 & 1 \\
\hline C9 & 0 & 0 & 0 & 1 & 0 & 1 & 0 & 0 & 0 & 0 & 0 & 0 & 1 \\
\hline C10 & 1 & 0 & 2 & 3 & 0 & 4 & 1 & 1 & 1 & 0 & 0 & 1 & 2 \\
\hline C11 & 1 & 0 & 1 & 2 & 0 & 3 & 1 & 0 & 1 & 0 & 0 & 0 & 1 \\
\hline C12 & 0 & 0 & 1 & 1 & 0 & 2 & 0 & 0 & 0 & 0 & 0 & 0 & 1 \\
\hline C13 & 0 & 0 & 0 & 0 & 0 & 1 & 0 & 0 & 0 & 0 & 0 & 0 & 0 \\
\hline
\end{tabular}

Table 2a: Normalized direct relationship matrix

\begin{tabular}{|l|l|l|l|l|l|l|l|l|l|l|l|l|l|}
\hline & C1 & C2 & C3 & C4 & C5 & C6 & C7 & C8 & C9 & C10 & C11 & C12 & C13 \\
\hline C1 & 0,000 & 0,000 & 0,000 & 0,000 & 0,000 & 0,063 & 0,000 & 0,000 & 0,000 & 0,000 & 0,000 & 0,000 & 0,000 \\
\hline C2 & 0,063 & 0,000 & 0,063 & 0,125 & 0,000 & 0,188 & 0,063 & 0,063 & 0,063 & 0,000 & 0,000 & 0,000 & 0,125 \\
\hline C3 & 0,000 & 0,000 & 0,000 & 0,000 & 0,000 & 0,063 & 0,000 & 0,000 & 0,000 & 0,000 & 0,000 & 0,000 & 0,000 \\
\hline C4 & 0,000 & 0,000 & 0,000 & 0,000 & 0,000 & 0,000 & 0,000 & 0,000 & 0,000 & 0,000 & 0,000 & 0,000 & 0,000 \\
\hline C5 & 0,063 & 0,000 & 0,063 & 0,125 & 0,000 & 0,188 & 0,063 & 0,063 & 0,063 & 0,000 & 0,000 & 0,000 & 0,125 \\
\hline C6 & 0,000 & 0,000 & 0,000 & 0,000 & 0,000 & 0,000 & 0,000 & 0,000 & 0,000 & 0,000 & 0,000 & 0,000 & 0,000 \\
\hline C7 & 0,000 & 0,000 & 0,000 & 0,063 & 0,000 & 0,063 & 0,000 & 0,000 & 0,000 & 0,000 & 0,000 & 0,000 & 0,000 \\
\hline C8 & 0,000 & 0,000 & 0,000 & 0,063 & 0,000 & 0,125 & 0,000 & 0,000 & 0,000 & 0,000 & 0,000 & 0,000 & 0,063 \\
\hline C9 & 0,000 & 0,000 & 0,000 & 0,063 & 0,000 & 0,063 & 0,000 & 0,000 & 0,000 & 0,000 & 0,000 & 0,000 & 0,063 \\
\hline C10 & 0,063 & 0,000 & 0,125 & 0,188 & 0,000 & 0,250 & 0,063 & 0,063 & 0,063 & 0,000 & 0,000 & 0,063 & 0,125 \\
\hline C11 & 0,063 & 0,000 & 0,063 & 0,125 & 0,000 & 0,188 & 0,063 & 0,000 & 0,063 & 0,000 & 0,000 & 0,000 & 0,063 \\
\hline C12 & 0,000 & 0,000 & 0,063 & 0,063 & 0,000 & 0,125 & 0,000 & 0,000 & 0,000 & 0,000 & 0,000 & 0,000 & 0,063 \\
\hline C13 & 0,000 & 0,000 & 0,000 & 0,000 & 0,000 & 0,063 & 0,000 & 0,000 & 0,000 & 0,000 & 0,000 & 0,000 & 0,000 \\
\hline
\end{tabular}


Table 3a: Dataset and Reference Sequence

\begin{tabular}{|c|c|c|c|c|c|c|c|c|c|c|c|c|c|}
\hline & C1 & C2 & C3 & C4 & C5 & C6 & C7 & C8 & C9 & C10 & C11 & C12 & C13 \\
\hline A1 & 15,1 & 7,9 & 21,4 & 61,7 & 1,7 & 2,9 & 31,6 & 1,7 & 16,4 & 3,2 & 0,9 & 39,5 & 3,8 \\
\hline $\mathrm{A2}$ & 13,8 & 15,1 & 15,0 & 67,5 & 3,1 & 3,2 & 19,9 & 1,2 & 11,9 & 2,6 & 1,1 & 45,6 & 4,3 \\
\hline $\mathbf{A 3}$ & 14,5 & 21,9 & 13,8 & 67,7 & 3,9 & 2,9 & 24,3 & 1,1 & 11,5 & 2,4 & 1,2 & 47,4 & 4,5 \\
\hline$\overline{A 4}$ & 14,6 & 43,3 & 23,6 & 60,4 & 2,4 & 1,1 & 33,0 & 1,3 & 11,2 & 2,4 & 1,3 & 40,7 & 3,4 \\
\hline $\mathbf{A 5}$ & 14,5 & 72,2 & 13,8 & 62,1 & 3,7 & 3,8 & 33,3 & 1,3 & 10,6 & 3,0 & 1,1 & 50,4 & 4,9 \\
\hline A6 & 13,6 & 46,9 & 6,5 & 77,0 & 1,7 & 2,5 & 20,3 & 0,7 & 7,9 & 2,9 & 0,5 & 53,2 & 4,4 \\
\hline A7 & 13,7 & 136,1 & 12,9 & 68,5 & 6,0 & 6,8 & 19,5 & 0,4 & 4,1 & 2,9 & 1,3 & 62,3 & 5,0 \\
\hline$\overline{\mathrm{A8}}$ & 19,9 & 37,3 & 5,3 & 67,0 & 1,5 & 5,2 & 25,3 & 0,3 & 2,0 & 3,7 & 0,5 & 83,8 & 4,1 \\
\hline A9 & 13,9 & 130,4 & 7,3 & 73,9 & 2,3 & 1,9 & 22,3 & 1,2 & 12,7 & 3,2 & 1,1 & 55,5 & 4,4 \\
\hline A10 & 15,6 & 68,0 & 16,7 & 64,5 & 2,0 & 5,5 & 27,4 & 1,1 & 9,6 & 2,7 & 1,2 & 52,0 & 3,7 \\
\hline A11 & 13,8 & 66,8 & 14,5 & 67,5 & 4,1 & 4,5 & 24,1 & 0,8 & 8,1 & 2,4 & 1,1 & 51,4 & 3,8 \\
\hline A12 & 15,5 & 151,1 & 6,4 & 71,1 & 5,1 & 3,4 & 25,5 & 0,5 & 6,0 & 2,6 & 1,5 & 58,3 & 4,3 \\
\hline$\overline{\mathrm{A13}}$ & 18,6 & 31,2 & 12,2 & 33,8 & 1,0 & 2,3 & 56,5 & 1,7 & 11,6 & 2,5 & 1,4 & 42,1 & 0,7 \\
\hline A14 & 16,0 & 137,3 & 7,3 & 76,7 & 2,6 & 4,0 & 19,0 & 0,5 & 5,2 & 2,4 & 0,6 & 62,9 & 4,9 \\
\hline $\mathbf{A 1 5}$ & 17,6 & 119,2 & 13,4 & 44,1 & 2,2 & 0,2 & 50,8 & 2,0 & 13,7 & 5,3 & 0,8 & 54,9 & 3,5 \\
\hline A16 & 16,1 & 138,2 & 15,3 & 61,0 & 5,2 & 6,2 & 28,3 & 0,9 & 9,2 & 2,6 & 0,9 & 60,3 & 4,3 \\
\hline A17 & 20,7 & 33,3 & 11,8 & 57,9 & 0,0 & 0,5 & 40,4 & 2,4 & 14,2 & 4,1 & 2,2 & 52,2 & 2,1 \\
\hline A18 & 15,4 & 178,1 & 17,2 & 66,8 & 6,6 & 3,5 & 20,9 & 0,8 & 7,8 & 3,6 & 1,0 & 56,9 & 4,3 \\
\hline $\mathbf{A 1 9}$ & 15,7 & 200,7 & 7,3 & 64,7 & 6,1 & 2,0 & 31,8 & $-1,0$ & $-12,5$ & 1,7 & 2,3 & 76,9 & 4,0 \\
\hline$\overline{\mathrm{A20}}$ & 12,8 & 152,9 & 16,3 & 61,9 & 4,4 & 1,5 & 36,2 & $-0,3$ & $-2,9$ & 2,1 & 0,1 & 84,2 & 2,6 \\
\hline A21 & 15,8 & 214,2 & 10,3 & 71,5 & 3,0 & 1,8 & 23,2 & 0,2 & 2,6 & 3,2 & 0,5 & 67,2 & 3,5 \\
\hline $\mathbf{A 2 2}$ & 15,6 & 65,7 & 11,9 & 68,1 & 6,1 & 3,8 & 29,6 & 0,2 & 2,0 & 2,4 & 0,9 & 70,0 & 5,6 \\
\hline $\mathbf{A 2 3}$ & 15,0 & 43,1 & 17,6 & 62,6 & 2,8 & 3,5 & 23,4 & 1,3 & 11,0 & 3,0 & 1,1 & 49,0 & 3,2 \\
\hline $\begin{array}{l}\text { Reference } \\
\text { Sequence }\end{array}$ & 20,7 & 214,2 & 5,3 & 77,0 & 0,0 & 6,8 & 56,5 & 2,4 & 16,4 & 5,3 & 2,3 & 39,5 & 0,7 \\
\hline
\end{tabular}


Table 4a: Grey Relational Coefficients

\begin{tabular}{|c|c|c|c|c|c|c|c|c|c|c|c|c|c|}
\hline & C1 & C2 & $\mathbf{C 3}$ & C4 & C5 & C6 & C7 & C8 & C9 & C10 & C11 & C12 & C13 \\
\hline A1 & 0,413 & 0,333 & 0,363 & 0,586 & 0,664 & 0,458 & 0,430 & 0,711 & 1,000 & 0,458 & 0,436 & 1,000 & 0,442 \\
\hline A2 & 0,365 & 0,341 & 0,486 & 0,696 & 0,514 & 0,478 & 0,339 & 0,596 & 0,764 & 0,396 & 0,468 & 0,784 & 0,409 \\
\hline $\mathbf{A 3}$ & 0,390 & 0,349 & 0,518 & 0,699 & 0,459 & 0,455 & 0,368 & 0,561 & 0,748 & 0,384 & 0,491 & 0,738 & 0,396 \\
\hline A4 & 0,393 & 0,376 & 0,333 & 0,566 & 0,582 & 0,368 & 0,444 & 0,604 & 0,737 & 0,380 & 0,521 & 0,949 & 0,481 \\
\hline A5 & 0,391 & 0,421 & 0,519 & 0,593 & 0,471 & 0,519 & 0,447 & 0,612 & 0,714 & 0,442 & 0,481 & 0,671 & 0,368 \\
\hline A6 & 0,357 & 0,381 & 0,886 & 1,000 & 0,660 & 0,431 & 0,342 & 0,507 & 0,629 & 0,432 & 0,377 & 0,620 & 0,399 \\
\hline A7 & 0,360 & 0,569 & 0,547 & 0,718 & 0,355 & 1,000 & 0,336 & 0,465 & 0,540 & 0,428 & 0,519 & 0,495 & 0,362 \\
\hline A8 & 0,833 & 0,368 & 1,000 & 0,685 & 0,688 & 0,680 & 0,376 & 0,452 & 0,501 & 0,534 & 0,383 & 0,335 & 0,423 \\
\hline A9 & 0,369 & 0,552 & 0,826 & 0,877 & 0,589 & 0,400 & 0,355 & 0,594 & 0,796 & 0,462 & 0,473 & 0,583 & 0,402 \\
\hline A10 & 0,439 & 0,414 & 0,446 & 0,635 & 0,621 & 0,710 & 0,392 & 0,573 & 0,681 & 0,412 & 0,489 & 0,641 & 0,451 \\
\hline A11 & 0,365 & 0,412 & 0,501 & 0,695 & 0,446 & 0,584 & 0,367 & 0,525 & 0,634 & 0,377 & 0,486 & 0,652 & 0,441 \\
\hline A12 & 0,434 & 0,620 & 0,894 & 0,785 & 0,394 & 0,491 & 0,377 & 0,469 & 0,581 & 0,403 & 0,568 & 0,542 & 0,409 \\
\hline A13 & 0,654 & 0,360 & 0,571 & 0,333 & 0,773 & 0,425 & 1,000 & 0,722 & 0,753 & 0,393 & 0,553 & 0,893 & 1,000 \\
\hline A14 & 0,455 & 0,573 & 0,826 & 0,987 & 0,564 & 0,540 & 0,333 & 0,474 & 0,562 & 0,380 & 0,386 & 0,488 & 0,368 \\
\hline A15 & 0,558 & 0,520 & 0,530 & 0,397 & 0,602 & 0,333 & 0,766 & 0,827 & 0,844 & 1,000 & 0,429 & 0,591 & 0,467 \\
\hline A16 & 0,460 & 0,576 & 0,479 & 0,574 & 0,389 & 0,855 & 0,399 & 0,535 & 0,669 & 0,399 & 0,442 & 0,518 & 0,404 \\
\hline A17 & 1,000 & 0,363 & 0,585 & 0,531 & 1,000 & 0,343 & 0,538 & 1,000 & 0,869 & 0,604 & 0,941 & 0,637 & 0,639 \\
\hline A18 & 0,427 & 0,741 & 0,436 & 0,679 & 0,333 & 0,501 & 0,345 & 0,522 & 0,628 & 0,509 & 0,458 & 0,562 & 0,409 \\
\hline A19 & 0,443 & 0,884 & 0,821 & 0,639 & 0,353 & 0,404 & 0,432 & 0,333 & 0,333 & 0,333 & 1,000 & 0,374 & 0,425 \\
\hline A20 & 0,333 & 0,627 & 0,455 & 0,589 & 0,431 & 0,382 & 0,480 & 0,393 & 0,428 & 0,360 & 0,333 & 0,333 & 0,570 \\
\hline A21 & 0,445 & 1,000 & 0,648 & 0,797 & 0,525 & 0,396 & 0,361 & 0,443 & 0,511 & 0,464 & 0,372 & 0,447 & 0,473 \\
\hline A22 & 0,435 & 0,410 & 0,583 & 0,709 & 0,352 & 0,525 & 0,411 & 0,445 & 0,500 & 0,386 & 0,430 & 0,423 & 0,333 \\
\hline $\mathbf{A 2 3}$ & 0,411 & 0,376 & 0,427 & 0,600 & 0,545 & 0,500 & 0,362 & 0,618 & 0,729 & 0,440 & 0,475 & 0,702 & 0,496 \\
\hline
\end{tabular}


Table 5a: Dimensionless Number for MOORA Analysis

\begin{tabular}{|c|c|c|c|c|c|c|c|c|c|c|c|c|c|}
\hline & C1 & $\mathrm{C} 2$ & $\mathrm{C3}$ & C4 & C5 & C6 & C7 & C8 & C9 & C10 & C11 & $\mathrm{C} 12$ & C13 \\
\hline A1 & 200 & 0,015 & 0,324 & 0,198 & 0,092 & 0,169 & 0,216 & 0,305 & 0,348 & 0,220 & 0,158 & 0,141 & 0,198 \\
\hline A2 & 184 & 0,029 & 0,227 & 0,217 & 0,171 & 0,187 & 0,136 & 0,221 & 0,254 & 0,178 & 0,189 & 0,163 & 0,221 \\
\hline A3 & 193 & 041 & 0,209 & 0,217 & 0,214 & 0,166 & 0,166 & 0,189 & 0,245 & 0,169 & 0,208 & 0,169 & 0,231 \\
\hline A4 & 0,194 & 0,082 & 0,358 & 0,194 & 0,130 & 0,067 & 0,226 & 0,228 & 0,239 & 0,165 & 0,230 & 0,145 & 0,175 \\
\hline A5 & 0,193 & 0,136 & 0,209 & 0,200 & 0,203 & 0,218 & 0,228 & 0,235 & 0,225 & 0,211 & 0,200 & 0,180 & 0,256 \\
\hline A6 & 0,180 & 0,089 & 0,098 & 0,247 & 0,093 & 0,143 & 0,139 & 0,131 & 0,167 & 0,204 & 0,090 & 0,189 & 0,229 \\
\hline A7 & 0,182 & 0,257 & 0,195 & 0,220 & 0,330 & 0,395 & 0,133 & 0,075 & 0,086 & 0,201 & 0,229 & 0,222 & 0,261 \\
\hline A8 & 0,265 & 070 & 0,081 & 0,215 & 0,082 & 0,305 & 0,173 & 0,056 & 0,043 & 0,258 & 0,098 & 0,299 & 0,211 \\
\hline A9 & 0,185 & 0,246 & 0,110 & 0,237 & 0,127 & 0,109 & 0,153 & 0,220 & 0,270 & 0,223 & 0,193 & 0,198 & 0,227 \\
\hline A10 & 0,208 & 0,128 & 0,253 & 0,207 & 0,111 & 0,317 & 0,188 & 0,200 & 0,205 & 0,190 & 0,206 & 0,185 & 0,193 \\
\hline A11 & 0,184 & 0,126 & 0,219 & 0,217 & 0,225 & 0,259 & 0,165 & 0,151 & 0,171 & 0,163 & 0,203 & 0,183 & 0,199 \\
\hline A12 & 0,207 & 0,285 & 0,097 & 0,228 & 0,278 & 0,197 & 0,174 & 0,081 & 0,127 & 0,183 & 0,261 & 0,208 & 0,221 \\
\hline A13 & 0,248 & 0,059 & 0,185 & 0,108 & 0,053 & 0,136 & 0,387 & 0,312 & 0,248 & 0,176 & 0,251 & 0,150 & 0,039 \\
\hline A14 & 0,212 & 0,259 & 0,110 & 0,246 & 0,140 & 0,233 & 0,130 & 0,088 & 0,110 & 0,165 & 0,101 & 0,224 & 0,256 \\
\hline A15 & 0,234 & 0,225 & 0,203 & 0,142 & 0,120 & 0,013 & 0,347 & 0,366 & 0,291 & 0,365 & 0,151 & 0,196 & 0,183 \\
\hline A16 & 0,214 & 0,261 & 0,231 & 0,196 & 0,285 & 0,362 & 0,193 & 0,162 & 0,196 & 0,181 & 0,165 & 0,215 & 0,225 \\
\hline A17 & 0,275 & 0,063 & 0,179 & 0,186 & 0,000 & 0,030 & 0,276 & 0,431 & 0,302 & 0,285 & 0,394 & 0,186 & 0,110 \\
\hline A18 & 0,205 & 0,336 & 0,260 & 0,214 & 0,363 & 0,205 & 0,143 & 0,147 & 0,166 & 0,247 & 0,180 & 0,203 & 0,221 \\
\hline A19 & 0,209 & 0,379 & 0,111 & 0,208 & 0,332 & 0,114 & 0,218 & $-0,188$ & $-0,265$ & 0,120 & 0,406 & 0,274 & 0,210 \\
\hline A20 & 0,170 & 0,289 & 0,246 & 0,199 & 0,239 & 0,086 & 0,247 & $-0,046$ & $-0,061$ & 0,147 & 0,024 & 0,300 & 0,134 \\
\hline A21 & 0,210 & 0,404 & 0,156 & 0,230 & 0,164 & 0,104 & 0,159 & 0,042 & 0,054 & 0,224 & 0,084 & 0,239 & 0,179 \\
\hline A22 & 0,207 & 0,124 & 0,180 & 0,219 & 0,333 & 0,222 & 0,203 & 0,045 & 0,042 & 0,170 & 0,153 & 0,249 & 0,292 \\
\hline A23 & 0,200 & 0,081 & 0,266 & 0,201 & 0,151 & 0,204 & 0,160 & 0,240 & 0,234 & 0,209 & 0,194 & 0,174 & 0,167 \\
\hline
\end{tabular}

